\title{
Pengelolaan Coorporate Social Responsibility Menurut Peraturan Perundang-undangan di Indonesia
}

\author{
Lili Naili Hidayah ${ }^{1}$, Raffles $^{2}$, Pahlefi ${ }^{3}$ \\ ${ }^{1,2,3}$ Fakultas Hukum Universitas Jambi \\ Kampus Pinang Masak J1 Raya Jambi Muaro Bulian Km 15 Mendalo Indah -Jambi \\ Correspondence email: lilinailihidayah@unja.ac.id; raffles@unja.ac.id; pahlefi@unja.ac.id
}

\begin{abstract}
Abstrak. Corporate Social Responsibility (CSR) merupakan salah satu kewajiban yang harus dilaksanakan oleh perusahaan sesuai dengan isi Pasal 74 Undang-Undang Nomor 40 Tahun 2007 tentang Perseroan Terbatas. Tujuan penelitian ini adalah untuk mengetahui tentang pengelolaan yang ideal CSR bagi perusahaan perseroan terbatas. Penelitian ini merupakan penelitian normatif, dengan menggunakan pendekatan perundang-undangan dan pendekatan konseptual. Berdasarkan hasil penelitian ditemukan bahwa norma kewajiban CSR bagi perseroan terkesan tidak tegas, karena tanggung jawab sosial belum diatur secara tegas tentang mekanisme CSR secara spesifikdalam peraturan, standar "kepatutan"dan "kewajaran" dalam penganggaran CSR, wujud pelaksanaannya maupun siapa yang berkompeten menilai kewajaran dan kepatatutan tersebut harus jelas diatur dalam peraturan pemerintah agar pengelolaan CSR terarah dan terukur.
\end{abstract}

Kata Kunci: Corporate; Responsibility; Social

Abstract. Corporate Social Responsibility (CSR) is one of the obligations that must be carried out by companies in accordance with the contents of article 74 of Law Number 40 of 2007 concerning Perseroan Terbatas. The purpose of this study is to find out about the ideal management of CSR for limited liability companies. This research is a normative study, using a conceptual approach and legislative approach. Based on the results of the study found that the CSR obligation norms for the company seem indecisive, because Social Responsibility has not been explicitly set about CSR mechanisms specifically in regulations, standards "propriety" and "reasonableness" in CSR budgeting, the form of implementation and who is competent in assessing the reasonableness and propriety must be clearly regulated in government regulations so that CSR management is directed and measurable.

Keywords: Corporate; Responsibility; Social

\section{PENDAHULUAN}

Perusahaan maupun korporasi disadari atau tidak, akan membawa suatu dampak bagi lingkungan dimana perusahaan itu berada, baik itu menguntungkan maupun merugikan. Dampak yang menguntungkan misalnya akan memberi masukan bagi pemerintah melalui pajak, bisa juga dengan adanya perusahaan atau korporasi memberi keuntungan dengan adanya pembukaan lapangan kerja baru, maka akan mengurangi tingkat pengangguran dilingkungan sekitar perusahaan, aktivitas perekonomian lokalpun akan berkembang, pendayagunaan sumber sumber produksilokal, dan lain-lainnya. Disamping membawa keuntungan bagi masyarakat sekitar juga, dapat membawa kerugian yang dapat berupa disfungsi dan polusipada kawasan pemukiman masyarakat, berkurangnya daya guna sumber, terjadinya bermacam-macam masalah baru terkait dengan masyarakat dan lingkungan, marginalisasi sebagian orang yang tidak memiliki akses ke dalam industrialisasi, perpindahanpenguasaan dana, dan alat-alat produksiekonomi kepadapelaku usaha dalam korporasiserta beragamdampak yang tidak positif lainnya. ${ }^{1}$

Ketika dampak itu menguntungkan bagi masyarakat sekitar, tentu tidak akan membawa keprihatinan bagi beberapa kalangan, namun adanya dampak negatif dari perusahaan inilah yang menyebabkan munculnya keprihatinan dari beberapa kalangan, yang akhirnya menggulirkan isu akan perlunya dunia usaha memasukkan masalah tanggung jawab sosial sebagai bagian integral dalam dunia usahanya.

Walaupun perkembangan ekonomi telah mengalami peningkatanyang signifikandibandingkansebelumnya, faktanya Indonesia masih mengalami permasalahan sosiologis yang cukup serius. Menghadapi situasi sosiologis dan politis yang semakin rumit di era otonomi daerah, maka Corporate Social Responsibility (untuk selanjutnya di sebut dengan Corporate Social Responsibility atau CSR) salah satu pilihan dalam mengembangkan kesejahteraan masyarakat. ${ }^{2}$

Amanat Konstitusi Republik Indonesia menegaskan bahwa pemanfaatan kekayaan bumi Indonesia adalah bagi kemakmuran dan kesejahteraan seluruh bangsa setinggi-tingginya, maka diharapkan pemerintah berwenang menerapkan norma, termasuk dalam hal ini adalah norma hukum yang kemudian diwujudkan dalam berbagai aturan

${ }^{1}$ Saipullah Hasan dan Devy Andriany, Pengantar CSR, Sejarah, Pengertian, dan Praksis, Cet. I (Yogyakarta: JOB Pertamina-Talisman Jambi Merang dan Pustaka Pelajar, 2015), hlm. 45.

${ }^{2}$ H. Budi Untung, Corporate social responsibility, Cet. 1 (Jakarta: Sinar Grafika, 2007), hlm. 2. 
hukum. ${ }^{3}$ Amanat dalam pasal tersebut menunjukkan bahwa sebesar-besar pemanfaatan sumber daya alam itu, maka proses pemanfaatan dengan menggunakan potensi alam yang ada perlu dilakukan dengan upaya yang sebaik mungkin, berdaya guna, terbuka, terus menerus, dan ramah dengan kondisi alam, dan mengandung aspek adil,supayamendapatkan faedah maksimal untuk kesejahteraan masyarakat secara terus menerus. Maknanya bahwa negara harus memastikan bahwa pengelolaan sumber daya alam ini tidak melenceng dan memberi dampak negatif atas pemanafaatan sumber daya alam ini. Selanjutnya untuk memastikan dalam pengelolaan sumber daya alam ini perusahaan atau korporasi itu tidak membawa dampak negatif, maka negara mengeluarkan beberapa peraturan yangmengatur pelaksanaan tentang CSR. Produk hukum yang pertama yaitu Undang-UndangNomor 40 Tahun 2007 tentang Perseroan Terbatas (untuk selanjutnya disebut UU Perseroan Terbatas).KetentuanCSR perusahaan ini diatur dalam Pasal 74 ayat (1) UU Perseroan Terbatasyang pada intinya mengandung isiuntukperseroan yang menjalankan usahadibidang dan/atau berkaita dengan sumber daya alam,wajib harus melaksanakan tanggung jawab social dan lingkungan. Inilah yang di maksud denganCorporate Social Responsibility (CSR). ${ }^{4}$

Tidak hanya hukumperseroan terbatassaja yang mengatur tentang hal tersebut (CSR), beberapa aturan lain yang menyinggung Corporate Social Responsibility (CSR), yaitu Undang-Undang Nomor 25 Tahun 2007 tentang Penanaman Modal (selanjutnya disebutUU Penanaman Modal), yang mengatur setiap investor mempunyai keharusan mengimplementasikan Good Corporate Governance (GCG) atau tata kelola perusahaan secara baik dan mengimplementasikan CSR perusahaan agar terwujud pertalian yang selaras, berimbang, dan relevan terhadap lingkungan, jiwa, aturan, dan kebiasaan rakyat sekitar.

Menurut Undang-Undang Nomor 32 Tahun 2009 tentang Perlindungan dan Pengelolaan Lingkungan Hidup (untuk selanjutnya disebut UU PPLH), bahwa hukum memfasilitasi masyarakat agar dapat melakukan tuntutan terhadap pihak manapun yang melanggar kepentingan rakyat banyak terhadapkawasan pemukiman dan kehidupan yang bagus dan higienis. Masyarakat memiliki hak untuk mempertahankan dan menuntut (upaya mempertahankan hak) untuk mendapatkan kondisi kawasan pemukiman yang baik dan higienis. Menurut Heinhard Steiger C.S upaya untuk mempertahankan hak (tuntuntan) memiliki dua fungsi, pertama The fungtion Defense, adalah hak membela diri terhadap gangguan luar yang merugikan lingkunga terdapat dalam Pasal 20 ayat (1) UUPLH. Kedua Action of Performance adalah hak menuntut melakukannya suatu tindakan agar lingkungan dapat dilestarikan, dipulihkan atau diperbaiki terdapat dalam Pasal 20 ayat (3) UUPLH, kedua fungsi itu kemudian diakomodasi dalam Pasal 34 UUPLH. ${ }^{5}$ Selain hal yang tersebut di atas, Undang-Undang Nomor 19 Tahun 2003 tentang Badan Usaha Milik Negara (selanjutnya disebut UU BUMN) juga mengatur tentang CSR.

UU Perseroan Terbatas memandatkan adanya pengaturan lebih teknis lagi mengenai CSR melalui Peraturan Pemerintah (PP). Artinya undang-undang tentang CSR harus ada aturan pelaksananya.Terbitlah kemudian PeraturanPemerintah Nomor 47 Tahun 2012 tentang Tanggung Jawab Sosial dan Lingkungan Perseroan Terbatas,mengatur mulai dari Pasal 2 sampai Pasal 8 dijelaskan tentang Tanggung Jawab Sosial dan Lingkungandan beserta teknis pelaksanaannya.

Hal tersebut selnjutnya berkembang dengan munculnyaperaturan daerah diseluruhwilayah Indonesia yang mengatur tentang pelaksanaan CSR, salah satunya adalah Peraturan Daerah Jambi Nomor 1 Tahun 2016 tentang Tanggung Jawab Sosial Perusahaan.Padahalsecaranyata-nyata ditegaskan dalam peraturan pelaksana CSR itu adalah kepentingan perseroan yang nantinya harus dipertanggung jawabkan kepada Rapat Umum Pemegang Saham.

Menurut John Austin, hukum adalah suatu kehendak atau keinginan dari pemegang kekuasaan. Seluruh ketentuan dalam penyelenggaraan pemerintahan, sosial dan politik berdasarkan ketentuan undang-undang, sehingga dengan perkataan lain UU Perseroan Terbatas, UU Penanaman Modal, UU PPLH, danaturan hukum lain berikut dengan peraturan pelaksananya adalah perwujudan dan kehendak pemerintah yang berlaku di wilayah Indonesia untuk rakyat (pengusaha) Indonesia yang harus dilaksanakan/ditaati. Di satu sisi pertanyaan mendasar mengapa CSR yang termasuk tindakan etis/moral dari suatu perusahaan dinormakan menjadi undang-undang yang wajib dilaksanakan oleh perusahaan akan menjadi kajian filsafat. Corporate Social Responsibilityyang pada awalnya merupakan kewajiban moral, akan tetapi dalam perkembangannya menjadi kewajiban hukum bagi korporasi.Berdasarkan hal tersebut, maka hal yang dikaji dalam artikel ini meliputi kajian secara filsafat, kajian penerapan CSR di Indonesia, dan kajian pengelolaan CSR dalam perspektif masa depan.

\section{METODE}

Artikel ini merupakan tergolong dalam penelitian doktrinal atau penelitian normatif. Penelitian ini mengacu kepada norma-norma dalam peraturan perundang-undangan dan praktik hukum dalam kegiatan bisnis di Indonesia. Pendekatan yang digunakan adalah pendekatan perundang-undangan atau statue approachdan pendekatan konseptual

\footnotetext{
${ }^{3}$ Mukti Fajar Nur Dewata, Tanggung jawab sosial perusahaan di Indonesia: studi tentang penerapan ketentuan CSR pada perusahaan multinasional, swasta nasional \& BUMN di Indonesia, Cet. 1 (Yogyakarta: Pustaka Pelajar, 2010), hlm. 6.

${ }^{4}$ Budi Untung, Op., Cit., hlm. 15.

${ }^{5}$ Ibid.
} 
atau conceptual approach.Pendekatan undang-undang digunakan karena ada telaah atau analisis terhadap undangundang yang berkaitan dengan masalah. Pendekatan konseptual atau conceptual approach digunakan karena ada konsep-konsep didalam teori hukum yang digunakan sebagai alat analisis. Fokus utama penelitian hukum normatif adalah mencari hubungan logis antar bahan hukum tersebut. Dari pencarian ini akan diperoleh asas atau prinsip hukum, hubungan korelasi antar prinsip hukum dengan prinsip hukum lainnya atau dengan peraturan hukum, sesuai atau tidak sesuainya antar peraturan hukum, dan lain-lain.

Data dalam hal ini berupa data sekunder, yang terdiri dari bahan hukum utama/pokok, dan bahan hukum tambahan. Bahan hukum yang dikumpulkan adalah bahan hukum primer dan bahan hukum sekunder. Bahan-bahan hukum tersebut didapatkan melalui riset kepustakaan dan riset dokumen, kemudian dianalisis secara kualitatif

\section{HASIL DAN PEMBAHASAN}

\section{Corporate Social Responsibilitydalam Perspektif Filosofis.}

Ontologi, epistimologi, dan aksiologi merupakan bahasan utama dalam kajian filsafat. Ontologi membicarakan mengenai hakikat (intisari) atau apa yang terkandung di balik darieksistensi sesuatu. Membahas masalah intisari tidak lain bicara tentang hal yang paling pokok, fundamental, atau fakta realitas. Intisari terhadap sesuatu hal adalah keadaan senyatanya atau yang paling mendasar terhadap hal yang dipermasalahkan. Upaya menemukan apa yang makna atau intisari yang tersimpan di balik suatu hal merupakan efektifitas berfilsafat, yaitu memikirkan sesuatu sampai tingkatan yang paling dasar, yang melakukan suatu kegiatan penelaahan dan menemukan intisari atau arti yang paling terdalam dari sesuatu. Hakikat akan terus mengeskplorasi dan mendapatkan jawaban secara hakiki terhadap sesuatu yang dibahas oleh nilai dari suatukenyataan. ${ }^{6}$ Ontologi berupayamembahashal paling mendasar yang tertuang pada tiap-tiap realitas faktual maupun kejadian yang terdapat pada tiap-tiap bentuknya.

Sedangkan epistimologi merupakan bahasan mengenai teknik atau cara dalam memperoleh segala sesuatu yang diketahui mengenai sesuatu itu. Selanjutnya makna aksiologi merupakan istilah berkaitan dengan teori nilai yang berhubungan dengan manfaat maupun sesuatu yang dimaksud oleh objek yang dibahas.

Berdasarkan apa yang tertulis di atas, bentuk CSR yang ada pada undang-undang disebut tanggung jawab sosial dan lingkungan (TJSL) pada intinya (ontologi) selaras dengan Pancasila khususnya sila ke-5. Hal iniselanjutnya dijabarkan dalam konstitusi Indonesia Tahun 1945.

Pasal 33 Konstitusi Republik Indonesia hasil amandemen merupakan landasan pengaturan selanjutnya dalam hal manajemenekonomi bangsa dan manifestasi kesejahteraan sosial. Hal tersebut merupakan rujukan dalam mewujudkan kebijakan ekonomi nasional. Kebijakan ini bisa dilihat melalui UU Perseroan Terbatas, UU Penanaman Modal, dan UU PPLH. Oleh karena itu, produk hukum tersebut dibuat pada hakikatnya untuk mewujudkan masyarakat Indonesia yang makmur. Berdasarkan hal ini, menarik untuk dibahas dalamPasal 74 UU Perseroan Terbatas yang memuat ketentuan mengenai Tanggung Jawab Sosial dan Lingkungan (TJSL) atau di kenal dengan nama Corporate Social Responsibility (CSR).CSRmerupakan kewajiban untuk melaksanakanbagi usaha berkaitan dengan Sumber Daya Alam.

Menelaahketentuan tersebutdi atas, bahwa implementasiCSR adalah sebuah kewajiban (mandatory) bagi korporasi. Hal ini selaras dengan ketentuan yang menyebutkan tentang kewajiban penerapan prinsip tata kelola perusahaan yang baik dan kewajiban pelaksanaan Corporate Social Responsibility (CSR), yaitu Pasal 15 UndangUndang Penanaman Modal.

Memperhatikan dengan seksamaaturan Pasal 74 UU Perseroan Terbatasdan Pasal 15 UU Penanaman Modal telah menentukan Tanggung Jawab Sosial dan Lingkungan (TJSL) ataupun Corporate Social Responsibility (CSR) sebagai sesuatu yang wajib oleh pelaku usaha dalam korporasi, dan untuk yang tidak melakukan kewajiban dalam undang-undang akan mendapat sanksi. Hal ini adalah bagian dari paham positivisme. Paham positivisme mengartikan hukum sebagai ius constitutum, yaitu hukum yang ada dan berlaku saat ini.Dengan arti kata lain,UUPerseroan Terbatas dan UU Penanaman Modal merupakan ius constitutum, yang dibuat sebagai produk nyata dari kekuasaan politik yang sah.

Landasan filosofis CSR adalah perbuatan etis/moral dari suatu korporasi, akan tetapi dirumuskan menjadi norm adalam undang-undang yang harus diimplementasikan oleh korporasi. Permasalahan tersebut bisa cermati bahwa eksistensi usaha yang ada apapun wujudnya akan senantiasa memunculkan efek. Efek yang muncul dapat diklasifikasikan kedalam dua efek, yaitu efek yang buruk dan efek yang baik.Efek yang baik diantaranya adalah adanya peluang kerja, meningkatnya penghasilan penduduk sekitar perusahaan, berkembangnya kawasan perumahan penduduk, dan lain-lain. Efek yang buruk senantiasa muncul yang berdampak instabilitas lingkungan hidup penduduk sekitar perusahaan, antara lain pencemaran iklim, terganggunya sumber air, lingkungan yang tidak tenang, dan lainlain.

${ }^{6}$ Abdul Ghofur Anshori, Filsafat hukum sejarah, aliran dan pemaknaan (Yogyakarta: Gadjah Mada University Press, 2006), hlm. 2. 
Eksistensi CSR menyediakan beragam faedah baik dilihat dari aspek yang berkaitan dengan masyarakat, ekonomis, maupun kawasan sumber daya alam.Akan tetapi, implementasi CSR di Indonesia cenderung tidak sedikit dijumpai hal yang perlu di tanggulangi mengingat belum terdapatnya ketentuan dan parameter CSR, persamaan pengertian, konsep, wujud, maupun peraturan pemerintah tentang CSR. Selain itu, perumusan norma CSR ke dalam undang-undang itu sendiri pun memunculkan persepsi yang tidak sama antara yang setuju dan yang tidak setuju. Beragamnya alasan yang tidak sepakat CSR sebagai suatu yang wajib dilakukan, karena berargumentasi bahwa CSR pada pemahaman sebagai keharusan saja.Pengusaha tidak memperdulikan landasan filosofinya dan efek yang telah terjadi sampai sekarang. ${ }^{7}$

Akibat negatif tersebut di atas harus diminimalisir melalui teknik mitigasi (upaya agar meminimalisir dampak buruk). Mitigasi bisa dikategorikan ke dalam mitigasi secara fisik dan mitigasi sosial. Mitigasi secara sosial dilakukan dalam bentuk $C S R .{ }^{8}$ Berpijak pada hal tersebut di atas, dalam prinsipnya secara umum kegiatan perusahaan dilandasi oleh nilai atau jiwa yang berasal dari pelaksanaan CSR. Hal ini disebabkan karena CSR merupakan acuan secara menyeluruh dalam perspektif sosial-ekonomi, kesejahteraan, dan ekosistem kawasan. Menjadikan korelasi yang seimbang, harmonis, dan selaras bagi perusahaan dan ekosistem kawasan sekitar perusahaan, nilai, norma, serta budaya penduduk setempat, merupakan dasar filosofis regulasi CSR dalam UU Perseroan Terbatas.

Korporasi jangan hanya semata-mata memanfaatkan sumber daya alam untuk kepentingan sendiri secara besarbesaran hanya untuk mendapatkan laba ekonomi saja, tetapi juga semestinya mengindahkan tanggung jawab sosialnya. Oleh sebab itu intisari CSR adalah nilai yang menjadi pijakan kegiatan korporasi, yaitu nilai keseimbangan, kewajiban, kejujuran, dan komitmen. Menjaga dari gangguan di luar kawasan ekosistem serta menjaga berhentinya keberlanjutan aspek hayati dan komunitas sosial dari efek buruk yang diakibatkan oleh dari kegiatan produksi korporasi adalah bentuk nilai keseimbangan yang merupakan kegiatan CSR sesungguhnya. Ketika kegiatan operasional korporasi menyebabkan efek negatif, maka keharusan korporasi wajib mengembalikan kondisi dalam keadaan yang normal terhadap efek yang dimunculkan terhadap kawasan sekitar dan penduduk, yaitu dengan cara pencegahan dini (menyediakan/membuat pembuangan sisa-sisa aktifitas korporasi yang merugikanlingkungan dengan perpedoman pada hukum positif) dan melakukan rehabilitasi lingkungan yang terganggu, serta memunculkan keseimbangan keberlangsungan hayati masyarakat sekitar korporasi.Sangat tidak logis jika di suatu daerah berdiri korporasi dengan usaha besar yang produksinya dinikmati seluruh penduduk dunia, namun penduduk di lingkungan korporasi tersebut mengalami kemiskinan dan mendapatkan lingkungan hidup yang tidak baik/tidak pantas (masyarakat menikmati pencemaran yang berasal dari pabrik, baik pencemaran udara, air, dan akses transportasi yang buruk karena efek dari pengangkutan bahan-bahan produksi pabrik dan sebagainya).

Aktivitas korporasi semestinya harus mencerminkan komitmen atas pembangunan visi dan misi sebagai bentuk nilai kejujuran.Terbuka atas informasi terhadap material produksi yang sehat bebas dari bahaya apabila dikomsumsi masyarakat, transparan kepada sesama kolega, staf dan langganan. Istilah yang berbeda nilai jujur yang merupakan visimisi dari korporasi kepada shareholder dan stakeholder, memperlihatkan tingkah laku yang beretika dari sebuah korporasi.

Kewajiban perusahaan dalam membentengi kawasan ekosistem alam terhadap disfungsi alam serta menjamin kesinambungan hayati kelompok kemasyarakatannya terhadap efek buruk yang diakibatkan oleh kegiatan operasional korporasi merupakan intisari atau hakikat dari CSR. Melalui eksistensi keharusan perusahaan dalam mengadakan perlindungan terhadap efek yang ada, maka aktifitas CSR tidak lagi hanya aktifitas perbuatan sosial semata atau program rutin korporasi yang bersifat kekinian dan tanpa ada paksaan atau kedermawanan perusahaan yang lebih mengarah kepada sifat kasihan badan usahakepada komunitas kemasyarakatannya dan lingkungan alam sekitarnya.

Berdasarkan hal itu, intisari CSR dapat di katakan dengan kalimat "menjalani secara bersama-sama dengan ikhlas untuk kebaikan umat manusia dan lingkungan alamnya". Oleh karena itu mengimplementasikan CSR sesuai intisarinya maka akan terwujud aksiologi CSR yaitu mewujudkan keseimbangan hubungan, baik orang dan alam serta mengadakan kemakmuran bagi rakyat banyak.

\section{Implementasi CSR di Indonesia}

Eksistensi dasar CSR, yaitu dalam upaya merevitalisasi kesanggupan perusahaan untuk menyesuaikan diri dengan lingkungannya, kelompok masyarakat tertentu serta pemangku kepentingan yang terkait dengannya, baik kedaerahan, nasional, maupun internasional. Dari aspek pelaksanaannya, seyogyanya supaya elemen-elemen korporasi, penguasa dan rakyat saling berhubungan dan menyokong, supaya CSR bisa diimplementasikan dengan

7 Sunaryo Sunaryo, “Corporate Social Responsibility (CSR) Dalam Perspektif Pembangunan Berkelanjutan," FIAT JUSTISIA 7, no. 1 (26 Oktober 2015): hlm. 265, https://doi.org/10.25041/fiatjustisia.v7no1.363.

${ }^{8}$ Sukandarrumidi, Corporate Social Responsibility (Yogyakarta: Bajawa Press, 2012), hlm. 30. 
menyeluruh, dengandemikian dalam proses lahirnya keputusan, mengimplementasikan keputusan, dan pertanggungjawabannya dapat diaplikasikan bersama. ${ }^{9}$

Konsep CSR dipahami sebagai kesungguhan korporasi untuk bertanggung jawab secara sosial dan lingkungan atas efek beroperasinya korporasi disuatu daerah. Tidak hanya mengambil keuntungan semata, namun diharapkan dengan program ini perusahaan dapat memperhatikan masyarakat dan lingkungan sekitar perusahaan. Menurut Trevino dan Nelson sebagaimana dalam bukunya Ernawan, Erni R, Business Ethics: Etika Bisnis, dan dikutip kembali oleh Ade Yuliany Siahaan, memberikan konsep CSR dalam bentuk piramida yaitu berupa 4 (empat) macam tanggung jawab yang harus dipertimbangkan secara berkelanjutan, yaitu ekonomi; hukum; etika dan berperikemanusiaan. Dijelaskan lebih lanjut tentang piramida tanggung jawab ini yaitu : 1)Pertanggungjawaban ekonomi yang menjadi dasarnya dan berpedoman pada peran utama bisnis dari sisi ekonomi sebagai proses barang dan jasa yang dikonsumsi oleh pelanggan; 2)Pertanggungjawaban secara legal yang juga acapkali dikaitkan dengan pertanggungjawaban moral, meluas kepada pertanggungjawaban hukum/legal dan menginginkan para pelaku usaha untuk melaksanakan perannya satu tingkatan di atas hukum; 3)Pertanggungjawaban etis meliputi pertanggungawaban pada umumnya, karena sedikit sekali cita-cita masyarakat diformulasikan dalam peraturan. Pertanggungjawaban sosial harus tergambar dari tingkah laku etis dari korporasi; 4) Pertanggungjawaban berperikemanusiaan/filantropis adalah pertanggungjawaban terhadap sesama yakni meliputi peran secara aktif korporasi dalam hal memajukan kesejahteraan manusia. ${ }^{10}$

Konsep lain mengenai CSR menyatakan perusahaan itu harus bertanggung jawab secara publik tidak hanya untuk kinerja keuangan perusahaan, namun juga untuk lingkungan sosial perusaaan, disamping itu juga harus mempromosikan hak asasi manusia, demokrasi, peningkatan masyarakat, dan tujuan pembangunan berkelanjutan di seluruh dunia. Konsep yang berikutnya adalah bahwa bisnis harus mencakup 4 komponen yaitu tanggung jawab sosial, tanggung jawab ekonomi, hukum, etika, filantrofik. Konsep ketiga adalah bahwa tanggung jawab sosial perusahaan berpedoman pada kelalaian manajemen dalam menetapkan rangkaian, konsep dan asas yang menjadi pedoman bagi perusahaan dalam membuat keputusan dan mengikuti perbuatan di luar persyaratan hukum yang diinginkan dalam hal nilai dan tujuan masyarakat, konsep berikutnya yaitu bahwa tanggung jawab ini mengidentifikasikan mengakomodasi kepentingan orang-orang yang terkena dampak tindakan organisasi, konsep yang terakhir yaitu bahwa perusahaan atau koorperasi membantu masyarakat dalam menyediakan kebutuhan dan jasa yang dibutuhkan dengan dana finansial dan non-finansial yang sedikit. ${ }^{11}$

Beberapa istilah CSR, salah satunya memberikan gambaran pengertian sebagai kegiatan bisnis yang memiliki kesungguhan yang tinggi bukan saja bertujuan meningkatkan benefit perusahaan, termasuk juga bertujuan menciptakan korelasi sosial-ekonomi lingkungan dengan menyeluruh, membumi dan berkesinambungan. Berdasarkan arti tersebut, dapat ditelaah bahwa satu hal mengenai implementasi CSR adalah kesungguhan yang tidak terputus untuk menciptakan kondisi yang sejahtera dari kumpulan rakyat sekitar.

Berdasarkan ketentuan Pasal 74 UU Perseroan Terbatas, menyebutkan bahwa "Perseroan yang menjalankan kegiatan di bidang sumber daya alam wajib menjalankan Tanggung Jawab Sosial dan Lingkungan", yang mana pengaturan ini bertujuan untuk tetap menciptakan konektifitas perusahaan secara selaras, seimbang, dan sesuai dengan lingkungan, nilai, norma, dan budaya masyarakat setempat. CSR ini adalah keharusan perusahaan yang dianggarkan dan diperhitungkan sebagai biaya perusahaan yang implementasinya dilaksanakan dengan mencermati faktor kepatutan dan kewajaran.

Kenyataannya pengaturan CSR dalam Peraturan Pemerintah Nomor 47 Tahun 2012tersebut masih belum jelas batasan dari kepatutan dan kewajaran ini.Terjemahan kepatutan dan kewajaran menjadi kabur dan bias, baik penafsiran dalam produk hukumnya maupun sumber hukum positif lainnya.Penjelasan Pasal 5 Peraturan Pemerintah No. 47 Tahun 2012 tersebut menyebutkan bahwa:

"Yang dimaksud dengan "kepatutan dan kewajaran" adalah kebijakan Perseroan, yang disesuaikan dengan kemampuan keuangan Perseroan, dan potensi risiko yang mengakibatkan tanggung jawab sosial dan lingkungan yang harus ditanggung oleh Perseroan sesuai dengan kegiatan usahanya yang tidak mengurangi kewajiban sebagaimana yang ditetapkan dalam ketentuan peraturan perundang-undangan yang terkait dengan kegiatan usaha Perseroan."

${ }^{9}$ Marthin, Marthen B. Salinding, dan Inggit Akim, "Implementasi Prinsip Corporate Social Responsibility (CSR) Berdasarkan Undang-Undang Nomor 40 Tahun 2007 tentang Perseroan Terbatas," Journal of Private and Commercial Law 1, no. 1 (19 Februari 2018): 32-111, https://doi.org/10.15294/jpcl.v1i1.12358.

${ }^{10}$ Erman Rajagukguk, "Konsep dan Perkembangan Pemikiran Tentang Tanggung Jawab Sosial Perusahaan," Jurnal Hukum IUS QUIA IUSTUM 15, no. 2 (2007): hlm. 173, https://doi.org/10.20885/iustum.vol15.iss2.art1.

${ }^{11}$ Christine A.Hemingway\& Patrick W, Maclagan Dalam Journal of Business Ethics, 2004, hlm. 33. 
Hal itu diartikan apabila dilakukan dengan kewajiban tanggun gjawab sosial perusahaan maka penyerahan kepada perusahaan tentang ukuran kepatutan dan kewajaran menjadi hal yang bersifat subjektif. Kepatutan dan kewajaran akhirnya mengiku tkepada kemampuan perseroan yang diselaraskan dengan keadaan financial perseroan. ${ }^{12}$

Pengertian dan bentuk dari sebuah "kepatutan dan kewajaran" itu sendiri merupakan hal yang sifatnya sangat universal, yang nantiny aakan membawa banyak penafsiran yang akan berbeda-beda setiap pemaknaannya. Bisa saja perusahaan atau korporasi menganggap bahwasannya pelaksanaan CSR yang mereka salurkan sudah sesuai dengan "kepatutan dan kewajaran" yangdimaksudkan oleh undang-undang, namun pada kenyataannya belum memenuhi bentuk dan pemaknaan dari kepatutan dan kewajaran tersebut oleh masyarakat, hal ini disebabkan karena belum adanya tolak ukur sebuah kepatutan dan kewajaran terkait dengan pelaksanaan CSR sebuah perusahaan. ${ }^{13}$

Tolok ukur atau standar dalam pelaksanaan CSR tentang kepatutan dan kewajaran yang tidak diberikan oleh UU Perseroan Terbatas dan juga akibat/ dari tidak dilaksanakannya CSR oleh perusahaan atau korporasi. Siapa yang berwenang menetapkan standar kepatutan tersebut jika itu pemerintah adalah pihak yang menetapkan standar kepatutan maka akan kesulitan dalam menetapkan standar tentang seberapa standar kepatutan tersebut agar tercipta peraturan yang berkeadilan. Bagamana mengukur kondisi kemampuan keuangan dalam perusahaan, kondisi pemangku kebijakan dalam perseroan, kerangka pengembangan perseroan dan keadaan ekonomi baik dalam skala kecil maupun luas, maka akan menciptakan standar variasi kepatutan yang berbeda-beda.${ }^{14}$

CSR ini nantinya yang melaksanakan adalah pengurus perusahaan berdasarkan rencana kerja tahunan perusahaan setelah sebelumnya memperoleh restu dari organ perusahaan selain Direksi berdasarkan acuan dasar perusahaan. Ini menjadi dilema ketika standar ukuran kemampuan keuangan perusahaan itu tidak jelas, apakah suatu perusahaan dapat atau dalam kondisi bisa atau mampu secara keuangan menjalankan CSR ini. Ketentuan Pasal 34 ayat (3) UU Penanaman Modal mengatur bahwa perusahaan, baik perseorangan maupun badan hukum, yang tidak melaksanakan kewajiban sebagaimana dimaksud dalam UU Penanaman Modal tersebut, maka akan dikenakan sanksi administratif dan sanksi lainnya menurut undang-undnag tersebut, yaitu sanksi peringatan tertulis, Pembatasan kegiatan usaha, Pembekuan kegiatan usaha dan/atau fasilitas penanaman modal, pencabutan kegiatan usaha dan/atau fasilitas penanaman modal.

Dalam ketentuan tersebut diatas menunjukkan bahwa CSR merupakan suatu kewajiban bagi setiap perusahaan dalam menjalankan kegiatan usahanya. Hal ini tentunya juga akan membuat dilema juga bagi jajaran direksi mau dilaksanakan ukuran kemampuan dan kepatutan belum ada, namun apabila tidak diimplementasikan maka akan dikenakan sanksi sesuai dengan haltersebut di atas.

Muhammad Rudi Rumengan dalam Farid Wajdi menyatakan bahwa payung hukum tanggung jawab sosial perusahaan (CSR) seperti UU Perseroan Terbatas, UU Penanaman Modaldan sebagainya tidak mengakomodasi untuk memaksa perseroan dalam melaksanakan CSR-nya, dalam hal ini pemerintah perlu memperjelas dan mempertegas tentang : 1.Peraturan Pemerintah untuk memperjelas besaran dana CSR yang harus dikeluarkan oleh perusahaan. Hal ini bertujuan agar perusahaan punya standar pengeluaran dana CSR sesuai dengan aturan yang telah ditetapkan oleh pemerintah; 2.Peraturan pemerintah atau keputusan menteri dibutuhkan untuk implementasi, pengawasan dan rincian sanksi apabila ada perusahaan yang tidak mengeluarkan dana CSR yang telah ditetapkan besarannya. Sanksi ini berfungsi sebagai warning bagi perusahaan yang masih enggan menjalankan tanggung jawab sosialnya. Sanksi ini bisa berupa teguran dan bahkan sampai pada pemutusan kontrak karya perusahaan.

Munculnya beberapa peraturan daerah atau Perda CSR yang mengacu pada ketentuan UU Perseroan Terbatas, UU Penanaman Modal, maupun dalam PP tentang tanggung jawab sosial (CSR), namun tidak ada dari aturan-aturan acuan itu yang secara kongkrit menjelaskan kewenangan Pemerintah Daerah membentuk Perda tentang CSR.

Dalam Undang-Undang Nomor 23 Tahun 2014 Tentang Pemerintahan Daerahdan aturanmengenai pembentukan peraturan perundang-undanganmendasari otoritas Pemerintah Kabupaten/Kota ataupun Provinsi untuk membentuk Perda. Perda dapat dibuat berdasarkan kepentingan rakyat setempat dan kemampuan setiap daerah.Isipengaturandalam Peraturan Daerah baik tingkat Provinsi maupun Kabupaten/Kota ditujukan untuk pelaksanaan otonomi daerah dan tugas pembantuan serta menampung kondisi khusus daerah dan/atau penjabaran lebih lanjut dari ketentuan yang lebih tinggi dalam tata urutan perundang-undangan. Walaupun ada kewenangan pemda atas

${ }^{12}$ Yeti Sumiyati dkk., "Kriteria Kepatutan Dan Kewajaran Dalam Tanggung Jawab Sosial Perusahaan Menurut Hukum Islam," Amwaluna: Jurnal Ekonomi Dan Keuangan Syariah 2, no. $1 \quad$ (31 Januari 2018):58-68, https://doi.org/10.29313/amwaluna.v2i1.3258.

${ }^{13}$ Rachmad Robby Nugraha, Siti Hamidah, dan Moch Fadli, "Makna Kepatutan Dan Kewajaran Berkaitan Dengan Tanggung Jawab Sosial Perusahaan Dalam Undang - Undang Nomor 40 Tahun 2007 tentang Perseroan Terbatas,” Jurnal Ilmiah Pendidikan Pancasila dan Kewarganegaraan 3, no. 2 (26 Desember 2018): 176-85.

${ }^{14}$ Ibid. 
dasar kepentingan masyarakat namun perlu digaris bawahi bahwa apa yang di atur Perda tidak boleh bertentangan dengan undang-undang yang lebih tinggi. ${ }^{15}$

Menurut Detania Sukarja pembagian urusan pemerintahan berdasarkan asas otonomi daerah tersebut diatas menjadi landasan hukum yang kerap digunakan untuk menjustifikasi kewenangan pemerintah daerah untuk membentuk Perda CSR. Keputusan MKRI ${ }^{16}$ menyebutkan bahwa aturan lanjut berkaitan dengan TJSL dirumuskan dalam Peraturan Pemerintah. Lebih lanjut, Mahkamah Konstitusi menyebutkan bahwa dengan diaturnya TJSL dalam UU Perseroan Terbatas, Pemerintah Kabupaten/Kota maupun Provinsi tidak memiliki kewenangan menerbitkan Perda yang berkenaan dengan TJSL, karena ketentuan TJSL dalam UU Perseroan Terbatas bersifat tegas dan rigit dan hanya bisa diatur dengan peraturan pemerintah. Sebagaimana telah diatur oleh UU Pemda dan UU Perseroan Terbatas, peraturan daerah jangan sampai terjadi konflik dengan ketentuan hukum di atasnya. Perda CSR dalam hal ini bertentangan dengan ketentuan Pasal 74 (4) UU Perseroan Terbatas, oleh sebab itu, dapat dibatalkan oleh pemerintah. Berdasarkan hal tersebut, pemerintah daerah tidak berwenang untuk membentuk Perda CSR. ${ }^{17}$

Dengan ketiadaan ketentuan apapun yang memberikan wewenang bagi pemerintah kabupaten/kota, maupunprovinsi untuk menerbitkan aturan tentang CSR, maka tidak didapati landasan aturan pemerintahan daerah kabupaten/kota dan provinsi membuat regulasi CSR dalam Perda.Terlebih lagi membuat CSR menjadi bagian dalam unsur-unsur penghasilan daerah seperti yang terjadi di Provinsi Sulawesi Tengah, dana CSR dicantumkan dalam APBD Perubahan 2016 sebagai dana hibah. ${ }^{18}$ Selain Provinsi Sulawesi Tengah, Provinsi Riau juga termasuk salah satu provinsi yang menerbitkan Perda yang berkaitan dengan CSR, yaitu Peraturan Daerah Provinsi Riau Nomor 6 Tahun 2012 tentang Tanggung Jawab Perusahaan di Provinsi Riau. ${ }^{19}$

Menurut Rahmatullah dalam Budi S. P. Nababan,terbitnya Peraturan Daerah CSR karena empat perkiraan pertama, ada anggapan pemerintah kabupaten/kota maupun provinsi berusaha tidak menanggung sendiri beban pertanggungjawaban proses pengambangan daerah kepada korporasi; kedua, ada kemauan mendapatkan penghasilan bagi biaya pembangunan daerah yang berasal dari pihak ketiga; ketiga, pemerintah kabupaten/kota dan provinsi berusaha mengadakan pengelolaan rencana kegiatan CSR melalui satu atap yang dikoordinir oleh pihak eksekutif di daerah, meskipun masih kabur bentuk dan teknis pelaksanaannya; keempat, pihak korporasi lemah dalam memprogram dan melaksanakan rencana kerja kegiatan CSR. ${ }^{20}$

Terhadap Perda tentang CSR yang banyak muncul diberbagai daerah, bagaimana peran dan fungsinya dalam pelaksanaan atau pengelolaan CSR maka dapat dikatakan Perda tersebut dapat dibatalkan oleh pemerintah. Peran dan Fungsi dari pemerintah daerah melalui perda baru bisa dilakukan apabila nantinya ada payung hukum yang jelas dari produk hukum yang mengatur mengenai CSR, yang memberikan aturan lebih lanjut tentang kewenangan dari pemerintah daerah untuk membuat Perda CSR. Jika masih aturan dalam undang-undang yang menjadi dasar CSR itu seperti UU Perseroan Terbatas dan UU Penanaman Modal masih kosong, maka kepastian hukum tidak akan tercapai. Jika nantinya ada aturan yang sebagai dasar dikeluarkannya Perda, peran dan fungsi Perda hanyalah dari aspek pengawasan (monitoring) program CSR perusahaan dan berlaku sebagai penerima informasi tertulis terkait perwujudan atas implementasi penyelenggaraan problematika yang ditemui (dalam hal ini penyelenggaraan tanggung jawab sosial perusahaan), sehingga dapat menciptakan penyelesaian problematika yang sedang berlangsung. Selain itu pemerintah daerah dapat berperan sebagai pihak yang menciptakan kondisi yang membuat terbentuknya ruang gerak dalam realisasi CSR sutau badan usaha, serta dalam hal penyelesaian permasalahan berkenaan dengan implementasi CSR, pemerintah daerah yang bias berfungsi sebagai mediator ini bisa diwakilkan oleh kepala desa, camat, anggota Dewan Perwakilan Rakyat Daerah, maupun polisi setempat. Akan tetapi, pemerintah daerah tidak memiliki wewenang sehubungan dengan realisasi dana tanggung jawab sosial perusahaan kepada masyarakat, karena hal tersebut mutlak berada pada perusahaan yang mengeluarkan dana CSRnya tersebut. ${ }^{21}$

${ }^{15}$ Ade Yuliany Siahaan, “Analisis Yuridis Atas Peran Pemerintah Daerah Terhadap Pelaksanaan Tanggung Jawab Sosial Perusahaan," USU Law Journal 6, no. 3 (11 April 2018): hlm. 11-19.

${ }^{16}$ Putusan MKRI No. 53/PUU-VI/2008 atas uji materiil Pasal 74 ayat (1) dan (2) UU PT.

${ }^{17}$ Detania Sukarja, "Kewenangan Pembentukan Peraturan Daerah Tentang Corporate Social Responsibility Oleh Pemerintah Daerah Dan Implikasinya Terhadap Iklim Penanaman Modal Di Daerah," Seminar Nasional Hukum Dan Ilmu Sosial 2 (1 Februari 2019): 30-42.

${ }^{18}$ Ibid.

${ }^{19}$ Fahrial, Andrew Shandy Utama, dan Sandra Dewi, Pemanfaatan Corporate Social Responsibility (CSR) terhadap Pembangunan Perekonomian Desa, Jurnal Wawasan Yuridika 3, No. 2 (September 2019). hlm. 251-263.

${ }^{20}$ Budi S.P.Nababan, Analisa Peraturan Daerah Tentang Tanggung Jawab Sosial Perusahaan Di Tengah Iklim Kemudahan Berusaha Dalam Perspektif Teori Perundang-undangan, Jurnal Rechs Vinding Badan Pembinaan Hukum Nasional. Kementerian Hukum dan HAM RI. Pusat Analisis dan Evaluasi Hukum Nasional Jl (Jakarta, Indonesia, t.t.).

${ }^{21}$ Ade Yuliany Siahaan dkk., Op., Cit. 


\section{Pengelolaan yang ideal CSR di masa depan.}

Menurut Masrizal, dalam penyelenggaraan CSR masih meninggalkan dua hal pokok. Pertama yaitu terdapat ketidakjelasan dalam kewajiban implementasi CSR, terutama subjek yang dimaksud dengan "perseroan yang menjalankan kegiatan usahanya yang berkaitan dengan sumber daya alam". Apakah Perseroan yang bukanberkaitan serta tidak melakukanaktifitasusahadenganmengambil keuntungan dari sumber daya alam, namun aktifitas produksinya memiliki efek pada kegunaan daya dukung terhadap potensi alam yang dapat dikembangkan untuk proses produksi? Kedua menurut Masrizal, selama initidak sedikit korporasi menganggap telah menyelenggarakan program CSR kepada para pemangku kepentingannya, namun pada kenyataan beberapa pemangku kepentingan merasa belum merasakan faedah bahkan tidak merasakan secara nyata sama sekali kegiatan dari korporasi. ${ }^{22}$

Berbeda dengan pendapat Saidi sebagaimana dikutip oleh Joko Rizkie Widokarti, implementasi CSR terdapat 4 (empat) bentu katau model CSR yang umumnya dilaksanakan oleh korporasi di Indonesia, yaitu bagaimana keterlibatan langsung di mana perusahaan menjalankan program CSR secara langsung dengan menyelenggarakan sendiri kegiatan sosial atau menyerahkan sumbangan kemasyarakat tanpa perantara. Untuk menjalankan tugas ini,sebuah perusahaan biasanya menugaskan salah satu pejabat seniornya, seperti corporate secretary atau public affair manager atau menjadi bagian dari tugas pejabat public relation. Selanjutnya bisa dengan melewati yayasan atau organisasi sosial korporasi. Korporasi biasannya mempunyai atau membuat yayasan di bawah lembaga atau grupnya. ${ }^{23}$ Bentuk ini memiliki kesamaan dari bentuk yang umumnya diaplikasikan di badan-badanusaha di negara dunia pertama (maju).Lazimnya, perusahaan/korporasimenyediakan biaya permulaan, dana rutinitas, atau dana tetap yang bisa dimanfaatkan secara rutin bagi aktifitas yayasan. Bentuk selanjutnya yaitu bisa dengan melakukan partnership dengan elemen lain. Perusahaan mengimplementasikan CSR lewat kemitraan dengan badan yang berpihak pada masyarakat/organisasi di luar pemerintahan. Model yang terakhir yaitu dengan member support atau joinpartner dalam suatu konsorsium. ${ }^{24}$ Korporasi ikut membuat, turut serta menjadi bagian atau memberikan dukungan dalam badan yang melakukan kegiatan yang berkaitan dengan kepentingan masyarakat yang diorganisir kepada kepentingan khusus untuk masyarakat luas.

Apabila dilihat sisi persamaan dan perbedaan terhadap bentuk yang lain, bentuk yang satu inimemiliki kecenderungan kepada kegiatan yang bersifat praktis, seperti bantuan dana untuk mengadakan bentuk fisik atas suatu fasilitas atau kegiatan. Pihak-pihak yang bergabung untuk melakukan kongsi atau perkongsian itu yang dipercayai oleh badan-badan usaha yang menyokongnya dengan lebih aktif berusaha mendapatkan partner kerjasama yang berasal dari kelompok badan yang beraktifitas secara teknis serta selanjutnya memajukan rencana kerja yang disetujui oleh seluruh elemen.

Berbagai model dalam penyelenggaraan CSR yang dikemukakan oleh Saidi, dilakukan oleh perusahaan atau korporasi di Indonesia. Asalkan dia mampu secara keuangan ketidakseragaman itu juga menunjukkan tidak adanya dasar bagaimana pengelolaan seharusnya CSR tersebut. Karena aturan perundang-undangan tidak jelas, maka perusahaanpun melakukan CSR dengan pola mereka sendiri dengan melihat referensi pelaksanaan CSR dari negara lain.

Dalam Peraturan Pemerintah Nomor 47 Tahun 2012tentang Tanggung Jawab Sosial dan Lingkungan Perseroan Terbatas (TJSL)disebutkan bahwa penyelenggaraanTanggung Jawab Sosial dan Lingkungan perseroan dibuat dengan mengindahkan kepatutan dan kewajaran. Pengertian mengenai "kepatutan dan kewajaran" merupakan kebijaksanaan perseroan, yang disesuaikan dengan kemampuan finansial korporasi serta kemungkinan bahaya ekonomi yang menyebabkan TJSL yang menjaditanggungan korporasi sesuai dengan aktifitas bisnisnya dengan tidak mereduksi keharusan yang termuat dalam aturan hukum yang dibuat dan disepakati pada saat pendirian dan penentuan aktifitas usaha badan usaha. Dapat dilihat bahwa ketentuan Peraturan Pemerintah tersebut tidak memberikan kejelasan terhadap berbagai isu dan kerancuan pengaturan dalam UU Perseroan Terbatas. Ketentuan PP justru tidak mengatur secara imperatif kewajiban penganggaran kegiatan Tanggung Jawab Sosial dan Lingkungan dalam anggaran perusahaan. ${ }^{25}$

PP juga tidak memperjelas standar "kepatutan"dan "kewajaran" dalam penganggaran Tanggung Jawab Sosial dan Lingkungan, wujud pelaksanaannya maupun siapa yang berkompeten menilai kewajaran dan kepatatutan tersebut. Ketentuan Peraturan Pemerintah Nomor 47 Tahun 2012 tentang Tanggung Jawab Sosial Lingkungan Perseroan Terbatas tersebut di atas justru menyebutkan bahwa penilaian terhadap "kepatutan dan kewajaran" merupakan kebijakan Perseroan atau dengan kata lain, perusahaanlah yang menilainya sendiri berdasarkan

\footnotetext{
${ }^{22}$ Masrizal.(2011).Menyoal Dilema Pengelolaan CSR di Daerah,http://padangekspres.co.id/?news=nberita\&id=179

${ }^{23}$ Joko Rizkie Widokarti, Masalah Dasar Pengelolaan Corporate Social Responsibility (CSR)Di (Indonesia: UniversitasTerbuka, t.t.).

${ }^{24}$ Pujiyono, Jamal Wiwoho, dan Triyanto, "Model Pertanggungjawaban Hukum Pelaksanaan Corporate Sosial Responsibility (CSR) Untuk Meningkatkan Kesejahteraan Masyarakat,” Yustisia Jurnal Hukum 5, no. 1 (1 April 2016): 73-91, https://doi.org/10.20961/yustisia.v5i1.8716.

${ }^{25}$ Ibid.
} 
kemampuan keuangannya. Maka untukmendapatkan pengelolaan yang ideal untuk Tanggung Jawab Sosial dan Lingkungan atau CSR di masa depan harus tegas diatur secara specifik dalam peraturan, mulai dari peraturan pemerintah sampai aturan dibawahnya, juga jelas bagaimana standar "kepatutan"dan "kewajaran" dalam penganggaran CSR, wujud pelaksanaannya maupun siapa yang berkompeten menilai kewajaran dan kepatatutan tersebut harus jelas diatur dalam peraturan pemerintah.

Selain itu, CSR yang konsepnya adalah merupakan keharusan moral dan kemudian dengan adanya pengaturan dalam peraturan perundang-undangan, menjadikan CSR menjadi kewajiban hukum. Pengaturan secara tegas dan spesifik merupakan suatu keharusan, hal ini disebabkan oleh beberapa alasan:

a. Kondisi kawasan yang kian mengkhawatirkan, adalah bagian dari latar belakang pentingnya pihak regulator membuat pengaturan sehingga dapat memberikan dukungan keberlangsungan kawasan kehidupan manusia. Perkembangan ekonomi yang merusak lingkungan akan mempunyai efek yang sangat buruk. Kerusakan kawasan ekosistem akan memberikan efek kegunaan peningkatan nilai ekonomi tidak bertambah, karena musnahnya sumberdaya alam dan mudah terkena dampak terhadap perubahan iklim/cuaca. Oleh karena itu, semestinya diskursus mengenai pembangunan ekonomi dan kesejahteraan masyarakat diatur menurut hukum. ${ }^{26}$

b. Korporasi yang merupakan salah satu elemen dari masyarakat sosial. Konsepsi sustainable development (pembangunan berkelanjutan) yang dilakukan korporasi dalam bentuk CSR. Merupakan hal yang urgen bagikorporasi dalam menyelenggarakan usahanya yang mempunyai tiga kepentingan yang harus dilayani dengan seimbang. Oleh karena itu fungsi eksekutif sebagai elemen yang mengadakan aturan serta otoritas yang mengawasi agar terselenggaranya CSR adalah hal yang tidak dapat diabaikan. ${ }^{27}$

\section{SIMPULAN}

Hakikat CSR pada dasanya adalah untuk mendapatkan suasana keseimbangan antara aktifitas korporasi dengan kawasan ekosistem kehidupan, atau dengan perkataan lainmembuatkonektifitas korporasi yang imbang, harmonis, dan serasi dengan lingkungan nilai, norma, serta kebiasaanrakyat setempat.Pengelolaantanggung jawab sosial belum diatur secara tegas tentang mekanisme CSR secara spesifikdalamperaturan. Untuk mendapatkan pengelolaan yang ideal dimasa yang akan datang maka diperlukan adanya mekanisme CSR secara specifikdalamperaturan, sehingga tidak ada perusahaan yang ragu-ragudalammelaksanakan CSR ini. Penentuan standar "kepatutan"dan "kewajaran" dalam penganggaran CSR, harus lebih jelas.Selanjutnya agar pelaksanaan CSR dapat berjalan menuju tercapainya maksud secara hakiki dari CSR, maka pihak korporasi perlu melakukan kegiatan kemitraan dengan komunitas-komunitas masyarakat sekitar perusahaan.

\section{DAFTAR PUSTAKA}

\section{Buku dan Jurnal}

Anshori, Abdul Ghofur. Filsafat hukum sejarah, aliran dan pemaknaan. Yogyakarta: Gadjah Mada University Press, 2006.

Budi S.P.Nababan, Analisa Peraturan Daerah Tentang Tanggung Jawab Sosial Perusahaan Di Tengah Iklim Kemudahan Berusaha Dalam Perspektif Teori Perundang-undangan, Jurnal Rechs Vinding Badan Pembinaan Hukum Nasional. Kementerian Hukum dan HAM RI. Pusat Analisis dan Evaluasi Hukum Nasional Jl. Jakarta, Indonesia, t.t.

Budi Untung, H. Corporate social responsibility. Cet. 1. Jakarta: Sinar Grafika, 2007.

Dewi, Dewa Ayu Putu Shandra. "KEWAJIBAN HUKUM TANGGUNG JAWAB SOSIAL PERUSAHAAN (CORPORATE SOCIAL RESPONSIBILITY) DALAM PERATURAN PERUNDANG-UNDANGAN DI INDONESIA." Kumpulan Jurnal Mahasiswa Fakultas Hukum 0, no. 0 (25 September 2015). http://hukum.studentjournal.ub.ac.id/index.php/hukum/article/view/1350.

—. "KEWAJIBAN HUKUM TANGGUNG JAWAB SOSIAL PERUSAHAAN (CORPORATE SOCIAL RESPONSIBILITY) DALAM PERATURAN PERUNDANG-UNDANGAN DI INDONESIA.” Kumpulan Jurnal Mahasiswa Fakultas Hukum 0 , no. 0 (25 September 2015). http://hukum.studentjournal.ub.ac.id/index.php/hukum/article/view/1350.

Hasan, Saipullah, dan Devy Andriany. Pengantar CSR, Sejarah, Pengertian, dan Praksis. Cet. I. Yogyakarta: JOB Pertamina-Talisman Jambi Merang dan Pustaka Pelajar, 2015.

Marthin, Marthin, Marthen B. Salinding, dan Inggit Akim. "IMPLEMENTASI PRINSIP CORPORATE SOCIAL RESPONSIBILITY (CSR) BERDASARKAN UNDANG-UNDANG NOMOR 40 TAHUN 2007 TENTANG

${ }^{26}$ Dewa Ayu Putu Shandra Dewi, "Kewajiban Hukum Tanggung Jawab Sosial Perusahaan (Corporate Social Responsibility) Dalam Peraturan Perundang-Undangan Di Indonesia," Kumpulan Jurnal Mahasiswa Fakultas Hukum 0 , no. 0 (25 September 2015), http://hukum.studentjournal.ub.ac.id/index.php/hukum/article/view/1350.

${ }^{27}$ Ibid. 
PERSEROAN TERBATAS." Journal of Private and Commercial Law 1, no. 1 (19 Februari 2018$).$ https://doi.org/10.15294/jpcl.v1i1.12358.

Mukti Fajar Nur Dewata. Tanggung jawab sosial perusahaan di Indonesia: studi tentang penerapan ketentuan CSR pada perusahaan multinasional, swasta nasional \& BUMN di Indonesia. Cet. 1. Yogyakarta: Pustaka Pelajar, 2010.

Nugraha, Rachmad Robby, Siti Hamidah, dan Moch Fadli. "MAKNA KEPATUTAN DAN KEWAJARAN BERKAITAN DENGAN TANGGUNG JAWAB SOSIAL PERUSAHAAN DALAM UNDANG - UNDANG NOMOR 40 TAHUN 2007 TENTANG PERSEROAN TERBATAS." Jurnal Ilmiah Pendidikan Pancasila dan Kewarganegaraan 3, no. 2 (26 Desember 2018).

Pujiyono -, Jamal Wiwoho, dan Triyanto -. "MODEL PERTANGGUNGJAWABAN HUKUM PELAKSANAAN CORPORATE SOSIAL RESPONSIBILITY (CSR) UNTUK MENINGKATKAN KESEJAHTERAAN MASYARAKAT." Yustisia Jurnal Hukum 5, no. 1 (1 April 2016). https://doi.org/10.20961/yustisia.v5i1.8716.

Rajagukguk, Erman. "Konsep dan Perkembangan Pemikiran Tentang Tanggung Jawab Sosial Perusahaan." Jurnal Hukum IUS QUIA IUSTUM 15, no. 2 (2007). https://doi.org/10.20885/iustum.vol15.iss2.art1.

Siahaan, Ade Yuliany. "Analisis Yuridis Atas Peran Pemerintah Daerah Terhadap Pelaksanaan Tanggung Jawab Sosial Perusahaan.” USU Law Journal 6, no. 3 (11 April 2018).

Siahaan, Ade Yuliany, Suhaidi Suhaidi, Sunarmi Sunarmi, dan Jelly Leviza. "ANALISIS YURIDIS ATAS PERAN PEMERINTAH DAERAH TERHADAP PELAKSANAAN TANGGUNG JAWAB SOSIAL PERUSAHAAN." USU LAW JOURNAL 6, no. 3 (18 April 2018).

Sukandarrumidi. Corporate Social Responsibility. Yogyakarta: Bajawa Press, 2012.

Sukarja, Detania. "Kewenangan Pembentukan Peraturan Daerah Tentang Corporate Social Responsibility Oleh Pemerintah Daerah Dan Implikasinya Terhadap Iklim Penanaman Modal Di Daerah.” Seminar Nasional Hukum Dan Ilmu Sosial 2 (1 Februari 2019).

Sumiyati, Yeti, Jejen Hendar, Taty A. Ramli, dan M. Faiz Mufidi. "KRITERIA KEPATUTAN DAN KEWAJARAN DALAM TANGGUNG JAWAB SOSIAL PERUSAHAAN MENURUT HUKUM ISLAM." Amwaluna: Jurnal Ekonomi Dan Keuangan Syariah 2, no. 1 (31 Januari 2018 ): 58-68. https://doi.org/10.29313/amwaluna.v2i1.3258.

Sunaryo, Sunaryo. "Corporate Social Responsibility (CSR) Dalam Perspektif Pembangunan Berkelanjutan." FIAT JUSTISIA 7, no. 1 (26 Oktober 2015). https://doi.org/10.25041/fiatjustisia.v7no1.363.

W, Christine A.Hemingway\& Patrick. Maclagan Dalam Journal of Business Ethics, 2004.

Widokarti, Joko Rizkie. Masalah Dasar Pengelolaan Corporate Social Responsibility (CSR)Di. Indonesia: UniversitasTerbuka, t.t.

\section{Peraturan Perundang-undangan}

Indonesia, Undang-undang Nomor 19 Tahun 2003 tentang Badan Usaha Milik Negara.

Indonesia, Undang-undang Nomor 25 Tahun 2007 tentang Penanaman Modal.

Indonesia, Undang-undang Nomor 40 Tahun 2007 tentang Perseroan Terbatas.

Indonesia, Undang-undang Nomor 32 Tahun 2009 tentang Perlindungan dan Pengelolaan Lingkungan Hidup.

Indonesia, Perturan Pemerintah Nomor 47 Tahun 2012tentang Tanggung Jawab Sosial dan Lingkungan Perseroan Terbatas.

Indonesia, Peraturan Daerah Provinsi Riau Nomor 6 Tahun 2012 tentang Tanggung Jawab Perusahaan di Provinsi Riau.

Indonesia, Peraturan Daerah Jambi Nomor 1 Tahun 2016 tentang Tanggung Jawab Sosial Perusahaan. 